\title{
Understanding adolescent girls' protection strategies against HIV: An exploratory study in urban Lusaka
}

Joseph Simbaya

Martha Brady

Population Council

Allison Stone

Population Council

Maya Vaughan-Smith

Population Council

Follow this and additional works at: https://knowledgecommons.popcouncil.org/departments_sbsr-pgy

Part of the Demography, Population, and Ecology Commons, Domestic and Intimate Partner Violence Commons, Family, Life Course, and Society Commons, Gender Equity in Education Commons, International Public Health Commons, and the Women's Health Commons How does access to this work benefit you? Let us know!

\section{Recommended Citation}

Simbaya, Joseph, Martha Brady, Allison Stone, and Maya Vaughan-Smith. 2010. "Understanding adolescent girls' protection strategies against HIV: An exploratory study in urban Lusaka." New York: Population Council. 


\section{Understanding Adolescent Girls' Protection Strategies against HIV: An Exploratory Study in Urban Lusaka}
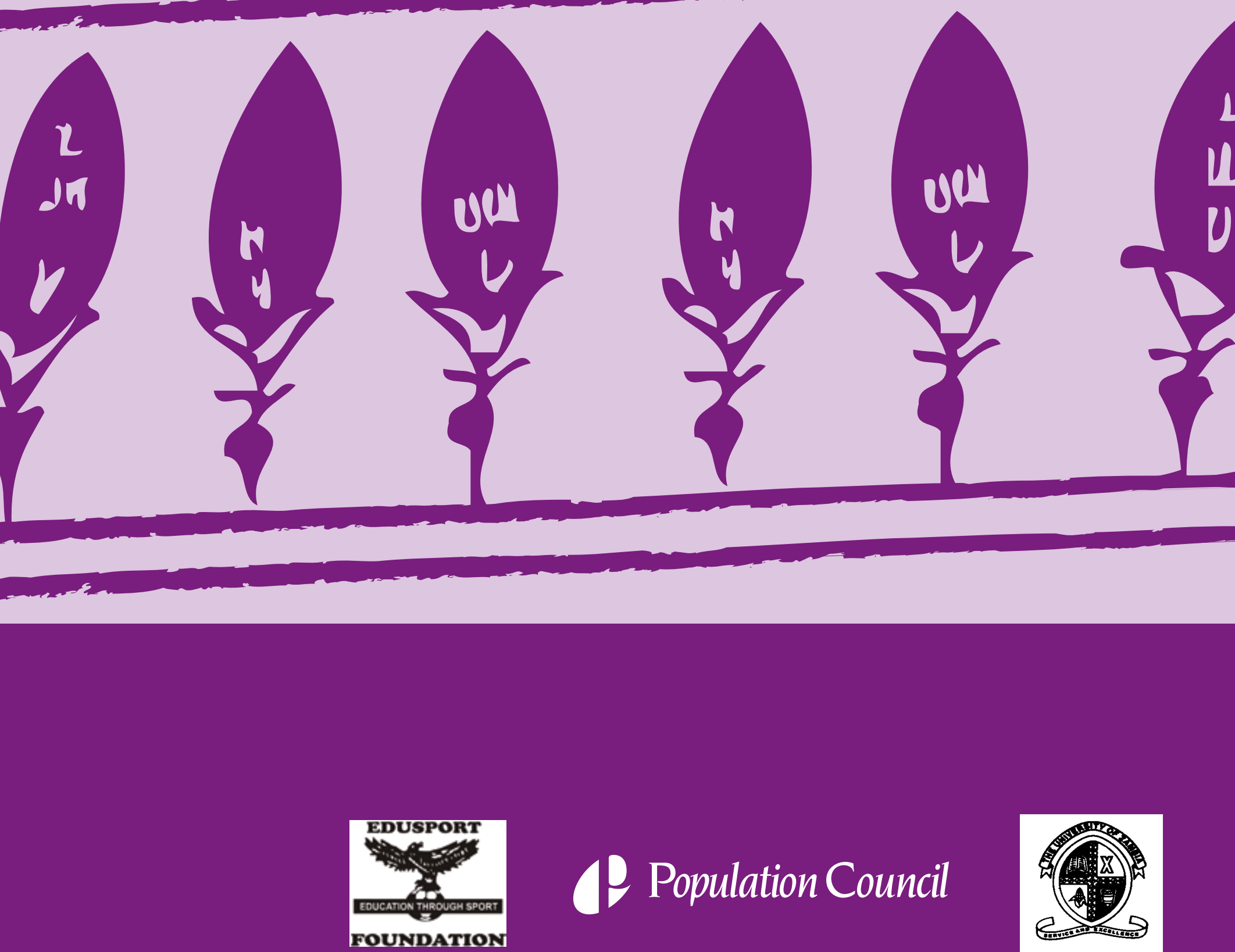

(P) Population Council

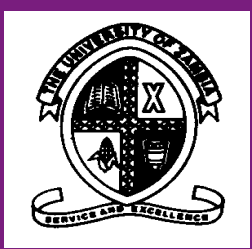





\section{Understanding Adolescent Girls' Protection Strategies against HIV: An Exploratory Study in Urban Lusaka}

Institute of Social and Economic Research, University of Zambia

Joseph Simbaya, Principal Investigator

\section{Population Council}

Martha Brady, Principal Investigator

Allison Stone

Maya Vaughan-Smith

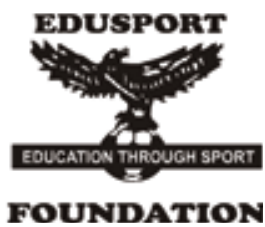

(2) Population Council

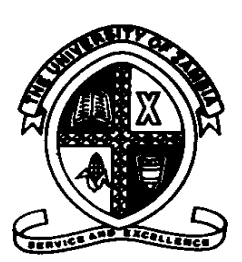




\section{ACKNOWLEDGEMENTS}

This study has benefited from the input of many. First and foremost we wish to thank the adolescent girls and young women of Lusaka who willingly gave of their time and shared their thoughts and experiences with us. We would also like to thank the team of interviewers: Mwango Mulambya, Estalla Nyimba, Christine Nambobe, Nancy Mukupa, Phallessy Mbindawina and Fridah Malupande, who painstakingly collected data, in sometimes difficult circumstances, to make this survey possible. In addition, we thank the field supervisors: Maureen Mwewa, Chipende Chizyuka and Alice Saili, who supervised the data collection and edited the questionnaires. We also thank Thomson Mwewa and Victor Kabwe for entry and processing of quantitative and qualitative data, respectively.

We highly value and appreciate the cooperation we received from the Central Statistical Office and the Resident's Development Committees in the four study sites for their invaluable support. Many thanks go to the Go-Sisters Program of EduSport for participation in the coordination of data collection. In particular, we would like to thank Annie Namukanga, Sharon Museke, and Florence Mwila for their diligent efforts.

Finally, we gratefully acknowledge the support of the Royal Danish Ministry of Foreign Affairs for the Population Council's work on Girls' Protection Strategies against HIV/AIDS.

\section{(2) Population Council \\ The Population Council conducts research worldwide to improve policies, programs, and products in three areas: HIV and AIDS; Poverty, Gender, and Youth; and Reproductive Health.}

Published: October 2009. Updated July 2010.

Population Council

One Dag Hammarskjold Plaza

New York, New York 10017 USA

Telephone: +1 2123390500

Facsimile: +1 2127556052

www.popcouncil.org

Suggested citation: Brady, Martha, Joseph Simbaya, Allison Stone, and Maya Vaughan-Smith. 2010. "Understanding adolescent girls' protection strategies against HIV: An exploratory study in urban Lusaka.” New York: Population Council.

(C) 2010 The Population Council, Inc. 
TABLE OF CONTENTS

ACRONYMS i

INDEX OF TABLE AND FIGURES ii

EXECUTIVE SUMMARY 1

INTRODUCTION 2

Study objectives $\quad 3$

Study design 3

Study setting: Description of Lusaka's informal settlements 3

RESEARCH METHODOLOGY 4

Data collection $\quad 4$

Respondent selection 4

Data analysis 4

Ethical considerations $\quad 5$

STUDY FINDINGS

Socio-demographic background $\quad 5$

Schooling status 6

Marital status 6

$\begin{array}{ll}\text { Partnerships change with age } & 7\end{array}$

Economic security and insecurity in the household 8

Economic activity and types of work done by girls 8

Social support networks 9

Sense of safety: Community, school, and personal 9

Girls' perceptions of sexual violence at school, community, and home 12

$\begin{array}{ll}\text { Personal experience with non-consensual sex } & 14\end{array}$

HIV testing knowledge, risk perception, and HIV prevention 14

Family planning knowledge and use 19

Menstruation and menstrual management $\quad 21$

$\begin{array}{ll}\text { Sports participation and role models } & 22\end{array}$

SUMMARY AND CONCLUSIONS 24

REFERENCES $\quad 26$ 



\section{ACRONYMS}

$\begin{array}{ll}\text { AIDS } & \text { Acquired immunodeficiency syndrome } \\ \text { CSA } & \text { Census Standards Areas } \\ \text { CSO } & \text { Central Statistics Office } \\ \text { DHS } & \text { Demographic and Health Surveys } \\ \text { EC } & \text { Emergency contraception } \\ \text { GRZ } & \text { Government of Zambia } \\ \text { HIV } & \text { Human immunodeficiency virus } \\ \text { IUD } & \text { Intrauterine Device } \\ \text { RH } & \text { Reproductive Health } \\ \text { SEA } & \text { Standard Enumeration Area } \\ \text { SRH } & \text { Sexual and Reproductive Health } \\ \text { STI } & \text { Sexually transmitted infection } \\ \text { WHO } & \text { World Health Organization }\end{array}$




\section{INDEX OF TABLE AND FIGURES}

\section{Tables}

Table 1: Demographic profile of study respondents $(\mathrm{n}=821) \quad 5$

Table 2: $\quad$ Sense of school safety $(\mathrm{n}=371) \quad 11$

Table 3: What do you do to keep yourself safe within your community? 12

Table 4: Girls' perceptions of sexual violence at school, community, and home

Table 5: What can a person do to reduce their chances of getting $\mathrm{HIV} / \mathrm{AIDS}$ ? (un-prompted; $\mathrm{n}=702$ )

\section{Figures}

Figure 1: Marital status, by age group $\quad 7$

Figure 2: Current partner status, by age group $\quad 7$

Figure 3: Primary source of economic support, by age group 8

Figure 4: Do you have many friends in your neighborhood? $(\mathrm{n}=819)$

Figure 5: Sense of community safety 10

Figure 6: Circumstance in which respondent feels most fearful $(\mathrm{n}=817)$

Figure 7: Do you know a place where you could go to get an HIV/AIDS test in your community? By age group 14

Figure 8: Have you ever been tested for HIV/AIDS? By age group 15

Figure 9: Do you believe you are at risk for HIV/AIDS from your partner? 15 By partner type

Figure 10: HIV/AIDS risk perception, by in-school status (15-19 year olds) 16

Figure 11: Have you ever heard of the female condom? By age group 18

Figure 12: Do you know where you can get a female condom? By age group 18

Figure 13: Do you know of any family planning services in this community? 19 By age group

Figure 14: Have you ever used the family planning services in this 19 community? By age group

Figure 15: Have you ever heard of emergency contraception? By age group 20

Figure 16: What methods for preventing pregnancy have you ever tried? 21 By age group

Figure 17: What type of sanitary supplies do you usually use? $(\mathrm{n}=799)$

Figure 18: Where do you get sanitary supplies from? $(\mathrm{n}=797)$

Figure 19: Which sports do you play? By age group 23

Figure 20: When did you last participate in any sports activity? By age group 23

Figure 21: Who is your favorite sports figure or athlete? $(\mathrm{n}=683)$ 


\section{EXECUTIVE SUMMARY}

Being young and female are two central aspects of vulnerability to HIV which intersect in the lives of adolescent girls. Both before and within marriage, girls and young women are especially vulnerable to contracting HIV as a result of both their biological susceptibility as well as their relative powerlessness within sexual relationships, the primary means of transmission. Girls and young women are disproportionally infected and affected by HIV and AIDS. This is true throughout much of sub-Saharan Africa, and it is the case in Zambia, one of the countries hardest hit by the HIV and AIDS epidemic. According to the 2007 DHS report, prevalence among 15-19 year old females is 5.7 percent (compared with 3.6 percent for males), and 11.8 percent among 20-24 year old females (compared to 5 percent for males). Like the adult female population, young female youth are twice as likely to be infected as male youth (CSO et al. 2009).

The current study provides a descriptive analysis of how adolescent girls and young women construct notions of risk and safety, their perceptions of HIV risk in particular, and what strategies they develop to protect themselves. The study is based on data collected through interviews with 821 young women aged 15-24 from four communities of urban Lusaka, and supplemented by qualitative data from focus group discussions and in-depth interviews. It is envisioned that information derived from this study can inform the development of innovative programming for vulnerable girls and young women in Lusaka.

As noted in other studies, overall knowledge levels about HIV/AIDS were high: 86 percent of respondents correctly knew that there are things a person can do to reduce her chances of getting HIV; 73 percent of all respondents knew where one could go for HIV testing. Risk perception of HIV/AIDS was also high: 38 percent of all respondents believe themselves to be at risk, and a considerable proportion (33 percent) had been tested for HIV at some point. A significantly greater proportion (60 percent) of those who had been tested was among the 20-24 year-old age group, compared to 22 percent in the younger age group (15-19). In terms of female protection products, 66 percent of all respondents had heard of the female condom (88 percent of the 20-24 year olds compared to 59 percent percent of 15-19 year olds). However, among those who had heard of the female condom, only 2 percent had ever used one. While efforts to bolster female condom promotion in Zambia have begun, more attention to this population may be warranted.

Lack of safety in the home, school, and community arose as a significant hazard to adolescent girls and young women in the study. Girls' perception of various risks to themselves directly or to "other girls their age" was striking: 37 percent of respondents reported having ever been threatened with physical violence, and 21 percent said they had been forced, pressured, coerced, or tricked into having sex. A full 86 percent of respondents believed that girls in their communities are pressured to do things they don't want to for money; 62 percent said girls in their school were forced to do things to receive better grades or to pass. Seventy percent of those surveyed reported that 
girls in their school were teased or verbally harassed, and 53 percent said girls in their school were sometimes touched or sexually harassed. In addition, many girls reported having heard of cases of forced or coerced sex in their community and school environment.

This study revealed that adolescent girls' social networks were not very strong overall. Only one quarter of respondents said they had many friends in their neighborhood, and less than one half said they knew of someone who would take them in if they needed a place to stay. These findings point to the need to strengthen and deepen girls' social support networks, improve access to the range of reproductive health services and products, and to create safe and supportive spaces for girls. The report points to several areas for potential program attention, including more focused attention on the structural and environmental drivers of girls' vulnerability.

\section{INTRODUCTION}

Adolescents comprise a large proportion of Lusaka's population: roughly 34 percent of people living in the nation's capital are between the ages of 10 and 24 (Mmari and Magnani 2003). This segment of the population faces a number of challenges to their health and well-being. In research by Slonim-Nevo and Mukuka, 19 percent of surveyed Zambian adolescents aged 10-19 in urban areas reported having unprotected sex in the previous two months. The authors also reported that 4 percent of urban adolescents were told by a health provider that they had a sexually transmitted infection, and that 8 percent of urban adolescents reported having traded sex for food or money in the two months prior to the survey (Slonim-Nevo and Mukuka 2005). Reported condom use, as in other high-prevalence areas of the epidemic, is low: only 17 percent of girls in a community-based sample of 2,300 Lusaka youth (10-24 years) reported consistent condom use.

Recent studies have demonstrated high levels of awareness among adolescents and young adults in Zambia both in terms of knowledge (Slonim-Nevo and Mukuka 2005) as well as knowing someone who has AIDS. However, despite high levels of awareness, several misconceptions about AIDS and HIV transmission are prevalent among Zambian youth. The Zambia Central Statistics office reported in 2002 that 30 percent of adolescent males and 32 percent of adolescent females said that there was no way to avoid AIDS. They also reported that 21 percent of males and 25 percent of females did not know that a person who appeared healthy could be infected with the virus; 30 percent of males and 24 percent of females believe AIDS could be transmitted by witchcraft. Finally, perception of women's power to negotiate safe sex is low among Zambian adolescents, with only 38 percent of males and 44 percent of females believing a woman could negotiate safer sexual behavior if her husband has a sexually transmitted disease (CSO, CBH, and ORC Macro 2003). 
Researchers noted that gender differences were widespread in data from a crosssectional survey of male and female adolescents aged 10-24 years in greater Lusaka. For example, being concerned about getting AIDS and knowledge about condoms were both positively associated with condom use for boys, but not for girls. The researchers posited that Zambian females often have limited power in sexual relationships, and called for gender-specific interventions to provide reproductive health information to female adolescents and to increase their negotiation skills and assertiveness within sexual relationships (Magnani et al. 2002).

\section{Study objectives}

The overarching goal of this research was to explore how adolescent girls and young women construct notions of risk and safety, particularly their perception of HIV risk, and what, if any, strategies they develop to protect themselves. We sought to:

- Identify the range of behaviors and actions girls take to protect themselves from reproductive health and HIV risks.

- Develop hypotheses regarding risk to reproductive health and autonomy, as well as physical safety among girls.

- Generate information to feed into the development of program interventions and strategies.

\section{Study design}

A cross-sectional survey of 821 adolescent girls and young women aged between 15-24 years was conducted in four compounds of urban Lusaka. The survey sample was randomly selected from the following compounds: Mtendere, Chiptata, Bauleni and Chawama. In addition to the quantitative survey, this study included a qualitative component, conducted only in the Chawama and Bauleni settlements. In-depth interviews (IDIs) were conducted with female peer leaders and coaches of the GoSisters program, ranging in age between 18-24, and focus group discussions were conducted with a sample of girls participating in the program. Go-Sisters is a project of the Edusport Foundation, a Zambian NGO which uses sports to empower youth. Experienced female interviewers were recruited and trained in qualitative research methods. This report includes key insights that emerged during the qualitative component of this study as well.

\section{Study setting: Description of Lusaka's informal settlements}

Zambia is one of the more urbanized countries in sub-Saharan Africa, with between 35-40 percent of the country living in an urban area. Roughly 70 percent of Lusaka's 1.3 million inhabitants live in poor, unplanned, or "informal" settlements (World Bank 2002). According to a 2002 World Bank report, 56 percent of households in Lusaka do not have electricity, 30 percent are without access to toilet facilities, 12 percent lack safe 
drinking water, and 80 percent live under the poverty level. The Lusaka compounds represented by this survey are government "informal" settlements. Chipata compound has a population of about 45,000 and 10,000 households. Residents of Chipata include members of the Bemba, Shona, and Nyakusa ethnic groups. Bauleni, a former farm worker's compound, has an estimated population of 50,000. Chawama compound is Lusaka's largest and most densely populated township, with a population of approximately 68,000 (Munich and Mayumbelo 2007). Mtendere compound was started in 1967 on a government initiative to relocate squatter settlements to a more planned community with public services. Mtendere residents are from various ethnic backgrounds (Aidoo and Harpham 2001).

\section{RESEARCH METHODOLOGY}

\section{Data collection}

This survey sample was randomly selected from the four compounds. Interviewers used the WHO cluster survey methodology for choosing households within the designated clusters in the four compounds. A team of six female interviewers slightly older than the survey's target population conducted the interviews after a five-day training workshop and field pretesting. The survey instrument was translated into the two predominant local languages, Bemba and Nyanja. Approximately 750 households were selected and 821 adolescents girls aged 15-24 were interviewed between April and 31 May 2008.

\section{Respondent selection}

In order to randomize the respondent selection process, site maps for the study's four target compounds were obtained from the Central Statistics Office. The compounds were demarcated into already existing clusters as defined by the Zambian Central Statistics Office (CSO). Maps were obtained from CSO with clearly indicated boundaries and demarcations. The CSO divides each compound into Census Standard Areas (CSA) and Standard Enumeration Areas (SEA). CSAs were selected using random sampling.

\section{Data analysis}

Two data entry screens were created in EpiData and data from questionnaires were edited and entered. The data were validated through a double entry validation program. After validation of duplicate files the data were then exported to STATA for further cleaning and analysis. Analyses of these data involved univariate and bi-variate analyses, including frequencies and distributions of selected study variables. 


\section{Table 1 Demographic profile of study respondents ( $n=821$ )}

Highest educational level completed

Never attended school

Some primary

24

170

Completed primary

302

Completed junior secondary

245

Some senior secondary

Completed senior secondary

70

10

Age, by compound

15-19

Chawama

161

19.6

Bauleni

147

17.9

Mtendere

120

14.6

Chipata

148

18.0

20-24

Chawama

Bauleni

Mtendere

46

61

5.6

Chipata

57

7.4

Other*

75

6

\section{Marital status}

Married/in union

$170 \quad 20.8$

Never married

$626 \quad 76.6$

Divorced/separated/widowed

21

2.6

Ethno-linguistic background**

Nyanja

Bemba

English

Lozi

Tonga

Other***

15

1.8

\section{Household composition}

\begin{tabular}{lrr|} 
(\# of HH members) & 40 & 4.9 \\
$1-2$ & 327 & 39.9 \\
$3-5$ & 333 & 40.7 \\
$6-8$ & 105 & 12.8 \\
$9-12$ & 14 & 1.7 \\
13-18 & \\
\hline \multicolumn{3}{l}{} \\
*Six respondents were from a compound other than one of the \\
survey's four target compounds \\
**Question phrased as: "Which language are you most conversant in?" \\
***Other includes Lunda, Kaonde, and Luvale in addition to those \\
ethnic groups not listed in the survey \\
\hline
\end{tabular}

\section{Ethical considerations}

This study was reviewed and approved by the University of Zambia's Research Ethics Committee. Informed consent of all young women involved in the study was sought prior to the start of an interview. Interviews were given in the appropriate local language depending on the respondent's language preference. Efforts to ensure confidentiality and privacy were critical. Interviews were conducted in a place "outside of earshot" of other household members, and only after permission was granted. Each team of interviewers had a field supervisor on site to ensure data quality and accountability. In addition, peer counselors were "on call" in the case of any of the respondents needing help or additional information or resources.

\section{STUDY FINDINGS}

\section{Socio-demographic background}

A total of 821 girls between ages 15-24 were interviewed, and all but six were from the four targeted compounds. Respondents were close to evenly distributed between the four target compounds, with a slightly greater proportion from Chipata compound, and a slightly lesser number from Mtendere compound. Respondents' ages ranged from 15 to 24, with a median age of 17 years and an average of 18 years. This bias toward the younger ages is most likely a reflection of: 1) the natural tendency of adolescents to move out of the compounds before they reach the older ages included in this sample; and 2) the fact that older girls are more likely to be working to support their households and therefore may not have been present at the time of the survey. For analysis purposes the respondents were divided into two age groups, 15-19 years old and 20-24 years old. There were 576 respondents in the younger age group and 245 respondents in the older age group (Table 1). Just under 99 percent of respondents stated they were Christian; eight respondents identified themselves as Muslim. The main languages spoken by study population were Nyanja (67 percent) and Bemba 
(19 percent). Nine percent reported that English was the language in which they were most fluent (Table 1). A full one-third of respondents live in a female-headed household.

\section{Schooling status}

Sixty-one percent $(\mathrm{n}=576)$ of the $15-19$ year olds reported currently being in school. Of the 20-24 year olds who answered this question $(n=239)$, only 7 percent were currently in school. Forty percent of respondents aged 15-19 stated that their highest grade completed was primary school, compared to 30 percent of women aged 20-24. Nineteen percent of women in 20-24 year old age group had completed senior secondary school, however, this group also had a greater percentage who had never attended school ( 5 percent of women 20 to 24 year olds vs. 2 percent of 15 to 19 year olds). This finding is not surprising, as the older respondents may have missed the increased emphasis on girls' education in recent years. In addition to formal schooling, ten percent of all the respondents had received other adult education or job training.

\section{What do girls think about the importance of education?}

Almost universally, girls appreciated the importance of education and believe that it holds a key to success. There was widespread belief that girls who complete their education are able to find jobs easier, get better jobs, and are wealthier. Some noted that girls who are educated speak better English and "look smart" and have more knowledge. Girls also mentioned that those who are educated are future leaders, are more knowledgeable about their rights, and can achieve greater success in life.
"If you finish school, you can get a job and be able to buy everything you want."

-FGD participant

"Someone who has been to school can get married but space her children, one or two are enough. But someone who hasn't been to school can have 10 children when she doesn't have the foundation to care for them ... just suffering."

-FGD participant

\section{Marital status}

Marriage is not a simple dichotomy (married vs. not married), rather there are different kinds of partnerships, unions, and processes leading up to marriage. Interviewers probed on issues of co-habitation, polygamous unions and marriage. Fifty-four percent of respondents aged 20-24 were currently married or cohabitating, compared to 8 percent of respondents aged 15-19. One woman had been widowed while another 20 were either separated or divorced (Figure 1).

The average age of marriage among respondents was slightly younger than 18 years of age. Among the married 15-19 year olds ( $n=47), 13$ percent were married before the age of 15, 55 percent were married between the ages of 15 and 17, and 32 percent were married when they were 18 or 19 years old. Among the married 20-24 year olds $(n=134), 5$ percent were married before 15 years of age, 19 percent were 
Figure 1 Marital status, by age group

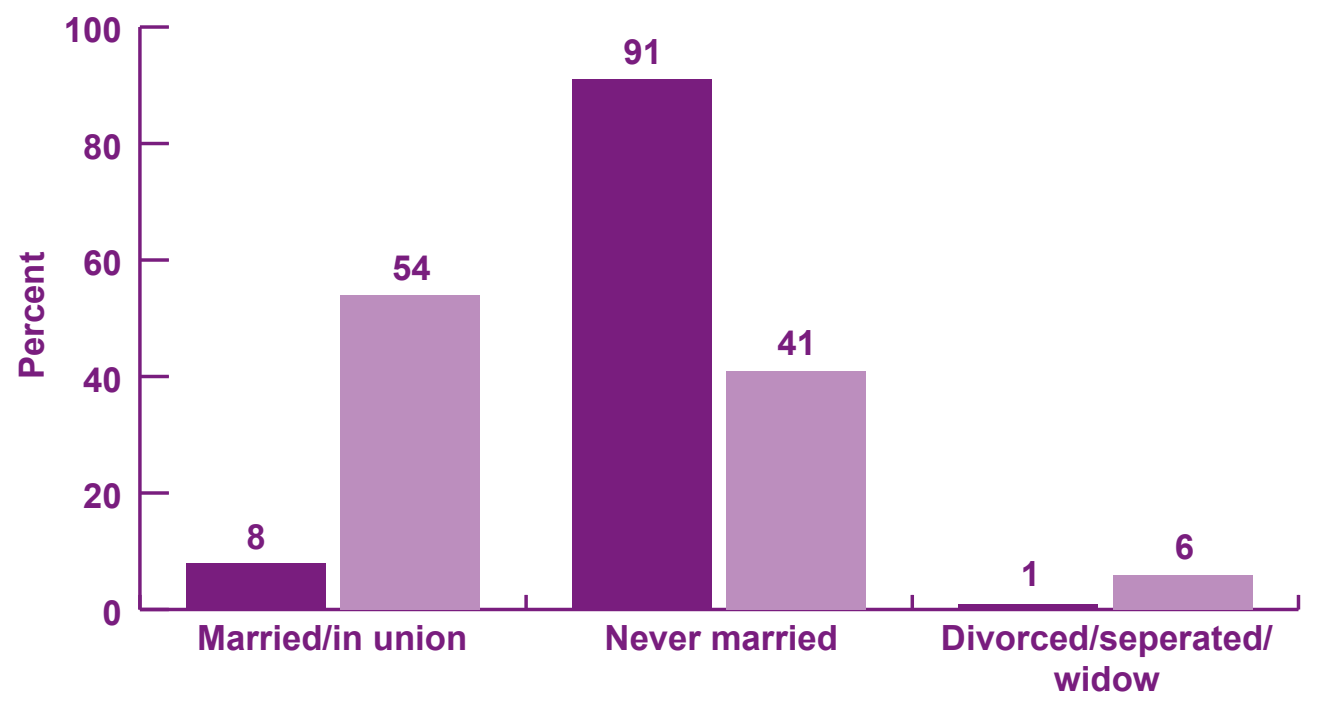

$15-19(n=581)$

$20-24(n=239)$

married between 15 and 17 years of age, 70 percent were married between the ages of 18 and 21, and five percent were married between the ages of 22 and 24 .

\section{Partnerships change with age}

As girls age, the likelihood of having a partner increases. For example, 72 percent of the 20-24 year olds compared to 33 percent of the 15-19 report having a steady partner. Conversely many more of the younger adolescents report having no partner at all (56 percent of 15-19 year olds report having no partner as compared to 19 percent of the 20-25 year olds) (Figure 2).

Figure 2 Current partner status, by age group

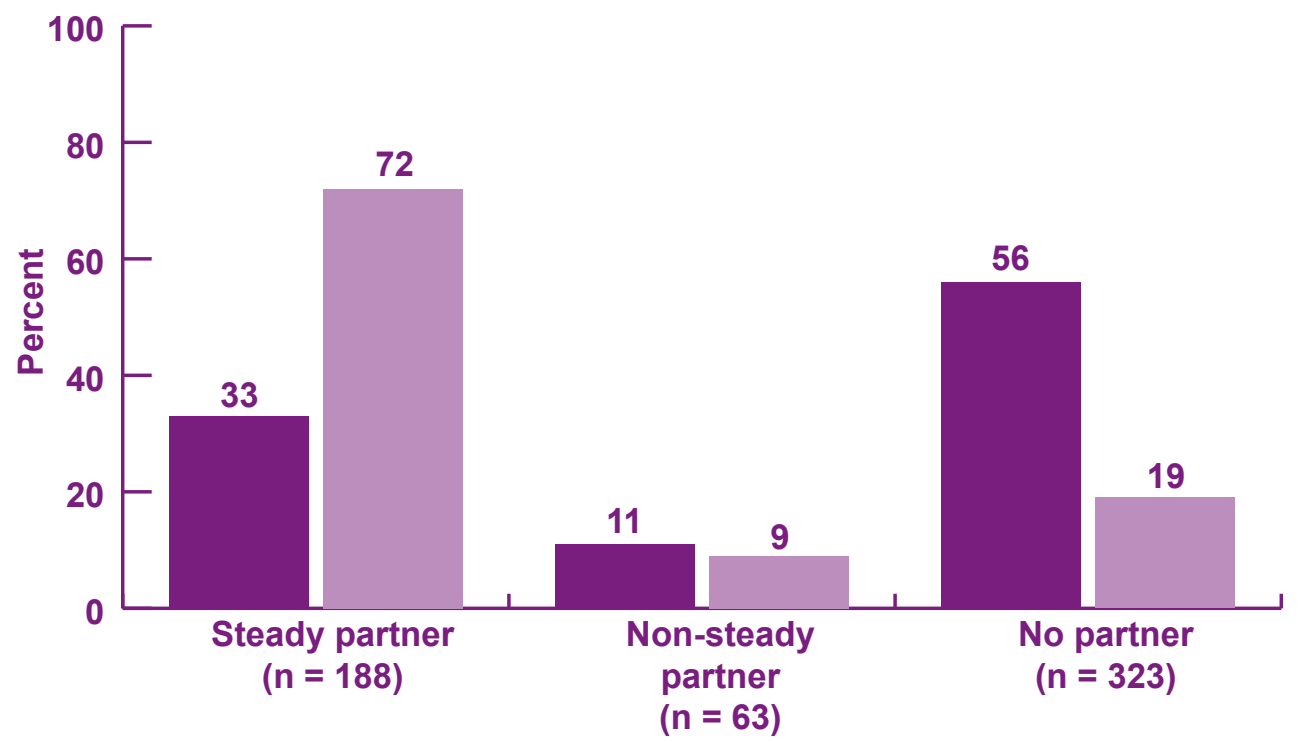

$15-19(n=574)$

$20-24(n=225)$ 


\section{Economic security and insecurity in the household}

Economic insecurity can play an important role in adolescent girls' vulnerability and their sense of powerlessness, thus we wanted to know about girl's economic activities and sources of economic support. Most girls mentioned that the major breadwinner in their household were parents or relatives, notably aunts and uncles. In some cases it was noted that a single parent was the breadwinner. Girls reported that their parents were in engaged in informal businesses as their main source of income; few spoke of formal employment. They mentioned piece work such as selling in the market, working as a maid, washing clothes, plaiting hair, chauffeuring, grave digging, and prostitution as the main economic activities in their communities. In general, the younger age group reported being supported either by a parent or other relative, while most of the respondents aged 20-24 reported being supported primarily by their spouse (Figure 3).

Figure 3 Primary source of economic support, by age group

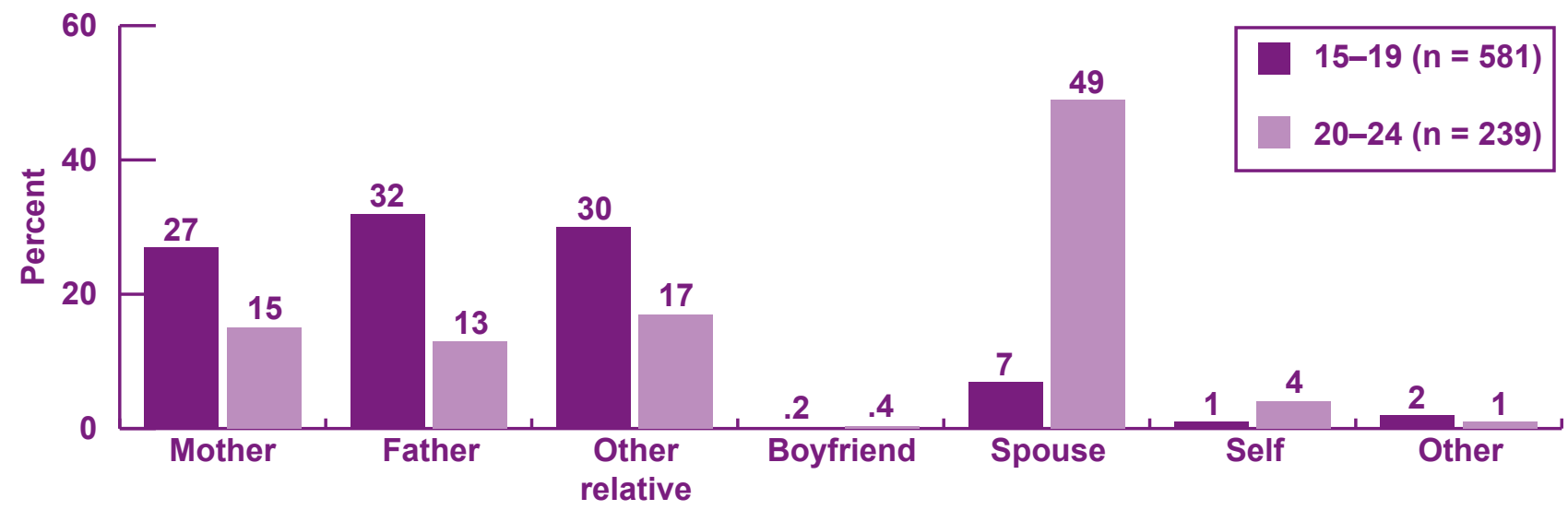

\section{Economic activity and types of work done by girls}

Twenty-seven percent $(n=224)$ of all respondents reported they did some type of income-generating activity, with significantly more of the older cohort (23 percent of 15-19 vs. 38 percent of 20-24 year olds) reporting so. Most of the respondents who reported working, stated they earned their income through hairdressing (39 percent), followed by market selling/trading (30 percent), and domestic chores (10 percent). Girls mentioned that they assist their family by helping their mothers cook and sell food. Over 70 percent of respondents described themselves as "self-employed". Fifty percent of those reporting some kind of employment earned less than 100,000 Kwacha per month (less than one dollar a day). Most of those in the younger age group were able to keep all of their income (64 percent), while the older cohort (20-24 years) shared their income with others (59 percent), likely reflective of their broader role in supporting the family. 


\section{Social support networks}

Figure 4 Do you have many friends in your neighborhood? $(n=819)$

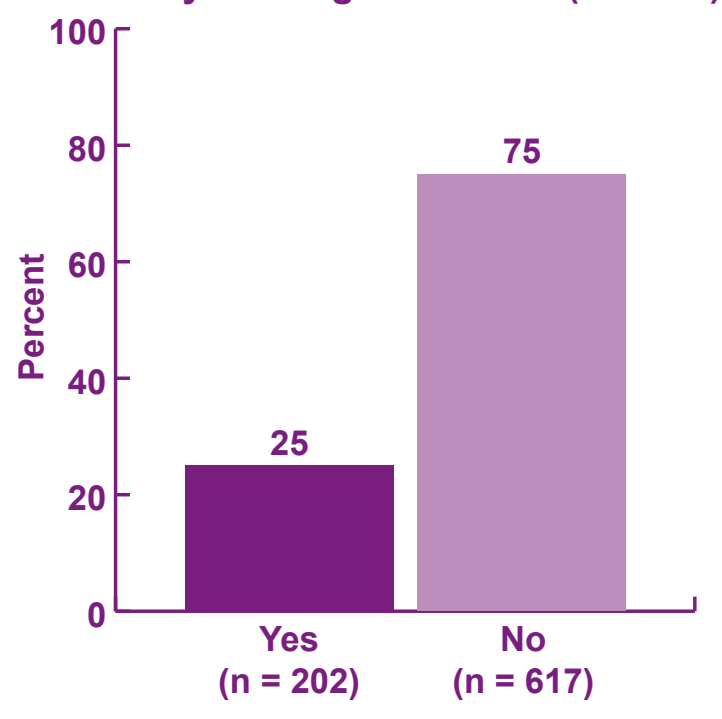

In addition to economic security, robust social networks can play a critically important role in girls' lives. While most respondents reported having people they could turn to if they had a problem, less than 50 percent said there was someone in their neighborhood who would take them in if they needed a place to stay. This seeming contradiction may be a question of what type of support is being sought. When needing advice or help with a problem, most respondents said they would turn to: a female friend (66 percent), mother (63 percent), sister (52 percent), aunt (36 percent) and grandmother (24 percent). Seeking someone to "take them in" if they needed a place to stay implied a greater level of support and engagement than was available to girls. Interestingly, girls who were not in school reported slightly fewer people they could turn to for support of any kind.

Perhaps the most striking finding was that only 25 percent of respondents said they had many friends in their neighborhood (Figure 4).

\section{Sense of safety: Community, school, and personal}

The importance of girls' safety—physical, emotional, sexual—within communities schools, at home, is increasingly recognized as a critical factor in girls' overall health and well-being. The lack of safety leaves many girls and young women vulnerable. It was striking how frequently the issue of safety, mobility, lack of trust in police and other authority figures arose throughout discussions with girls.

\section{How do girls define safety? What is a safe space for them?}

Notions of safety ranged from personal issues of bodily integrity to broader issues of peace and stability in the community. Examples of what focus group discussants said:

"It means that we are free to do what we want to do. It means the roads are safe when we are walking."

"Men don't defile or rape young ones—so we are safe."

"Everything is ok, and there are no bad activities in the community."

-FGD participant
In terms of safe spaces, overall girls identified home and church as the safest place, although some girls said "there are no places that are safe". Drinking places, buses, and crowded places were seen as unsafe. Even "relatively safe places" during the day were said to be unsafe at night. Some girls suggested that playing fields during the daytime can be safe for girls because they are open to the public and 
girls are in a group with their team. Basically, the overwhelming sense was that there is safety in numbers, during the daylight, and in open visible space.

Lack of confidence in civil protection. Lack of confidence in the police came up repeatedly in conversations with girls. While many girls felt the police could be helpful, there was also a general feeling that police would help only if there was an incentive for them. Girls remark that although some police do their job diligently, most of them usually ask for money. Many girls are reluctant to seek help from the police as they have nothing to give them. Overall, there was a striking lack of confidence on the part of many girls that there were viable community enforcement and protection mechanisms in place. In

"Some [police] can be trusted, others not. Yes they assist us in some cases and we trust them but not in everything... when you go there to report a problem... unless you give them money...K 50,000, that's when be can belp." -FGD participant fact, some girls felt the police were dangerous and participate in the criminal activities themselves.

\section{Community safety}

We attempted to measure girls' notions of safety at the community level by asking about a number of different scenarios. Figure 5 summarizes these situations and girls' responses to them.

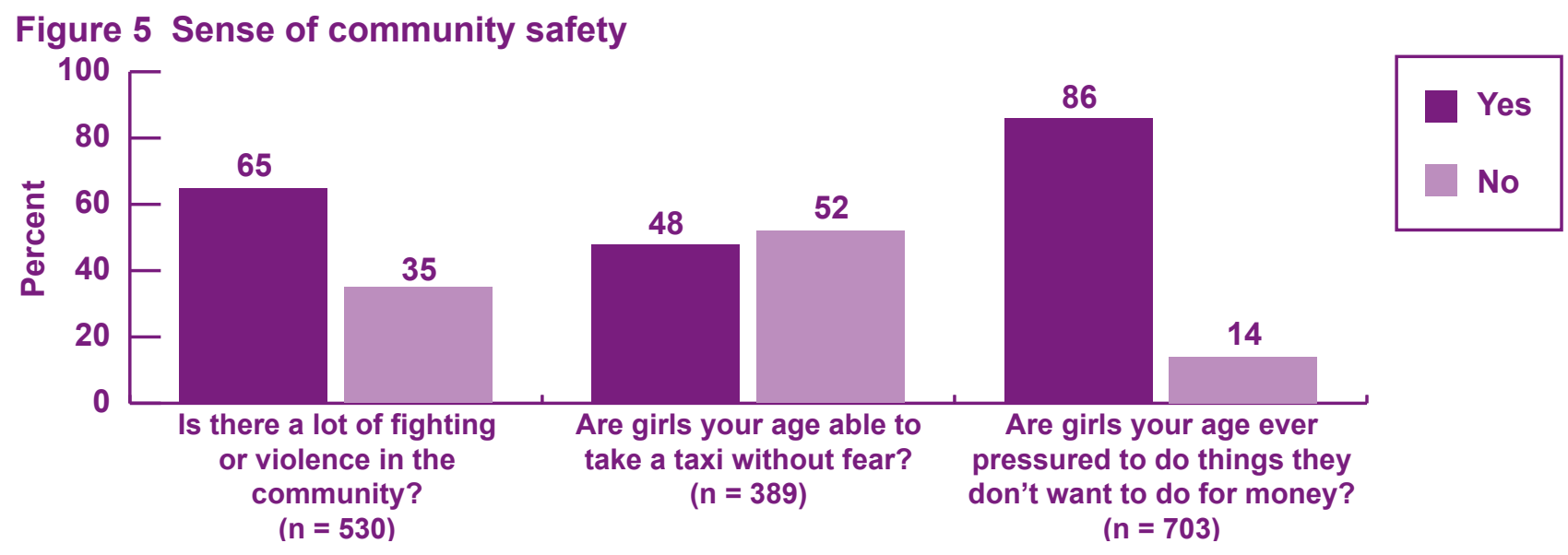

The issue of mobility and transportation arose often in our discussion with girls. There was a general sense of lack of safety while walking alone, particularly at night. In addition, most girls felt that taxis were unsafe, as were-although to a lesser extent—public buses. Girls' concerns about taxis include fear of abduction and/or kidnapping, as well as fear of violence, rape, or being attacked. Finally, "fear of Satanists" arose as a concern for girls in both instances.

"Even when you bave no money for school fees your parents tell you that they also don't have.... you go to a boy and have sex for money." -FGD participant 


\section{School safety}

Globally, school safety is increasingly recognized as a major environmental factor affecting the lives of young people, particularly girls. A number of recent surveys of girls' schooling experience indicate that schools are often unwelcoming, hostile, or actually unsafe for girls. Understanding girls' perceptions of and experience in their school environment is therefore critical to ensuring their safety.

Table 2 summarizes girls' responses to a number of situations concerning school safety. Thirty-four percent $(n=125)$ of school-going girls reported that there was fighting or violence in their school, and 60 percent $(n=223)$ said there was theft/ stealing in their school. Seventy percent said that girls in their school were teased or verbally or sexually harassed; 62 percent said girls were sometimes forced to do things they didn't want to for better grades or in order to pass, and 53 percent said that girls in their school were molested, touched, or sexually harassed physically.

\begin{tabular}{|c|c|}
\hline & $\begin{array}{c}\text { Yes } \\
\text { n (percent) }\end{array}$ \\
\hline Is there fighting or violence in your school? & $125(34 \%)$ \\
\hline Are girls your age forced to do things they don't want to do for better grades or to pass? & $231(62 \%)$ \\
\hline Is there theft or stealing in your school? $(n=371)$ & $223(60 \%)$ \\
\hline Are girls in your school teased or sexually harassed? & $260(70 \%)$ \\
\hline Are girls in your school ever molested, touched, or sexually harassed physically? $(n=371)$ & $195(53 \%)$ \\
\hline
\end{tabular}

Figure 6 Circumstances in which respondent feels most fearful $(n=817)$

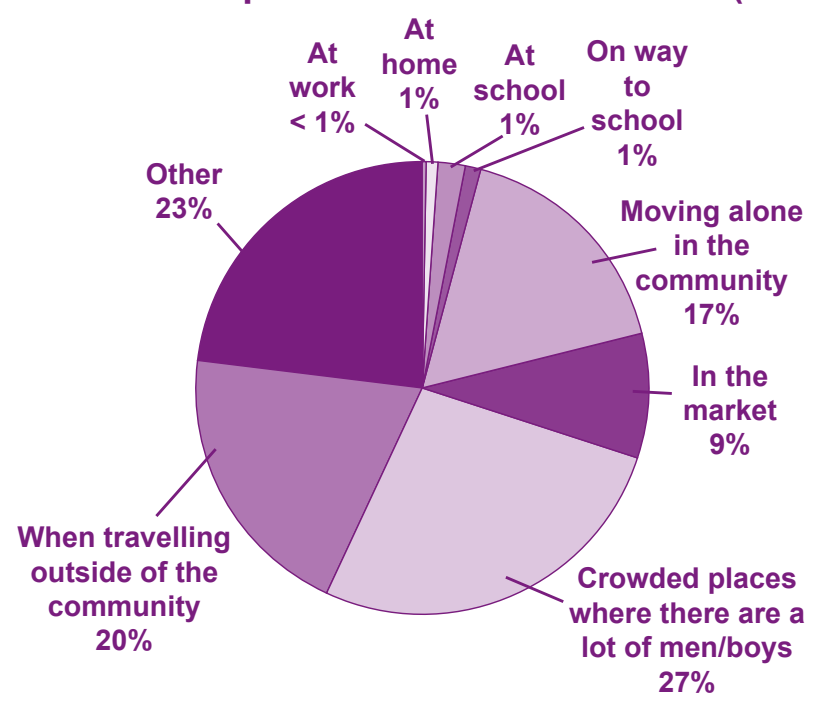

\section{Personal safety}

Respondents were asked to select one situation from a short list of scenarios in which they felt most fearful. The three circumstances in which respondents felt most fearful included: 1) crowded places where there are a lot of boys or men (27 percent), 2) when travelling outside of their community (20 percent), and 3) when moving alone in the community (17 percent) (Figure 6).

Similarly, respondents were asked to select from a short list the circumstances in which they felt least fearful. The majority of respondents (79 percent) felt the safest at home, with a smaller proportion (13 percent) feeling safest at church. Most respondents felt that: 1) thieves (86 percent), 2) too many drinking places (80 percent), 3) too 
many men and boys (62 percent), and 4$)$ drug abuse (60 percent) are factors present in their community that make it unsafe.

\section{How do girls respond to dangers in their communities? What protection strategies do they employ?}

Whether and how girls respond to the threats they face offers a glimpse into the protection strategies they employ. The vast majority of survey respondents reported taking some action to keep themselves safe within their communities; only 4 percent of respondents reporting that they do "nothing" to keep themselves safe. As shown in Table 3, the most common actions girls reported taking include: 1) avoiding moving at night (82 percent), 2) staying at home (82 percent), 3) avoiding crowded places where there are a lot of men/boys (67 percent), and 4) avoiding dark isolated places (61 percent).

\begin{tabular}{|lc|}
\hline Table 3 What do you do to keep yourself safe within your community? & Yes \\
& $n(\%)$ \\
\hline Move as a group $(n=816)$ & $148(18 \%)$ \\
Avoid moving at night $(n=818)$ & $673(82 \%)$ \\
Avoid dark isolated places $(n=818)$ & $497(61 \%)$ \\
Avoid being alone with a man $(n=817)$ & $396(48 \%)$ \\
Avoid crowded places where there are a lot of men/boys $(n=818)$ & $547(67 \%)$ \\
Stay at home $(n=818)$ & $671(82 \%)$ \\
Nothing $(n=818)$ & $31(4 \%)$ \\
\hline
\end{tabular}

It is noteworthy that most of these actions involve the girls themselves having to curtail their movements and avoiding places and men, rather than dedicated efforts to make places safe for girls and young women and address male predatory behaviors. However some girls noted that the legal system must ensure that laws regarding rape and defilement are enforced so that girls can be protected.

\section{Girls' perceptions of sexual violence at school, community, and home}

There was a general perception among girls that most perpetrators of rape, defilement and sexual abuse are people known to the girl. They listed potential perpetrators including relatives (uncles, cousins, brothers, and fathers) as well as boyfriends, neighbors, teachers, classmates, and the police. Insights from the qualitative research suggest that in general, girls do not trust men, because as one girl noted, "anyone can be a rapist". Perpetrators were said to use cunning methods such as asking for 
"T had a girl who was defiled by an uncle and the mother was a problem. She didn't want the information to come outside their home. Before the girl was very active and suddenly the girl became cold and isolated herself, I called her and counseled her nicely that's when she opened up and told me everything. Her mum stopped her. I went to the mother and explained to her the implications on the girl; the earlier we know about it the better. So we reported to the police, it wasn't easy, she feared the relative might be arrested. Lucky enough the child is okeay."

-In-depth interview with peer educator company, or sending a young girl to buy sweets or offering her sweets. Drug and alcohol were also implicated in fueling sexual abuse and violence against girls and women.

Thirty-six percent of respondents reported having heard of a schoolgirl in their community being forced to have sex with a teacher. Twenty-three percent had heard of a schoolgirl in their community being forced to have sex with a classmate, and 48 percent had heard of a girl forced to have sex with a relative from their own household. Overall, 60 percent of respondents reported having heard of a girl in their community being forced to have sex with a teacher, a classmate, or a relative. Respondents stated that approximately three-quarters of these incidents of sexual violence were reported to the victim's parents and 59 percent were reported to the police or a victim's support unit. According to the girls, the victim sought treatment from the local clinic or hospital in only 62 percent of these incidents (Table 4).

\begin{tabular}{|c|c|c|c|}
\hline & $\begin{array}{l}\text { Yes } \\
\mathrm{n}(\%)\end{array}$ & $\begin{array}{l}\text { No } \\
n(\%)\end{array}$ & $\begin{array}{l}\text { Don't know } \\
\text { n (\%) }\end{array}$ \\
\hline $\begin{array}{l}\text { Have you ever heard of a schoolgirl in this community who has been } \\
\text { forced to have sex with a teacher? }(n=818)\end{array}$ & $296(36 \%)$ & $522(64 \%)$ & $\mathrm{n} / \mathrm{a}$ \\
\hline In any of these incidents, did the girl stop attending school? $(n=296)$ & $182(61 \%)$ & $96(32 \%)$ & $18(6 \%)$ \\
\hline In any of these incidents, did the teacher stop teaching? ( $n=296)$ & $168(57 \%)$ & $109(37 \%)$ & $19(6 \%)$ \\
\hline $\begin{array}{l}\text { Have you ever heard of a schoolgirl in this community who has been } \\
\text { forced to have sex with a classmate her own age? }(n=816)\end{array}$ & $184(23 \%)$ & $632(77 \%)$ & $\mathrm{n} / \mathrm{a}$ \\
\hline $\begin{array}{l}\text { Have you ever heard of a girl in this community who has been forced to } \\
\text { have sex with a relative from within her household? }(n=817)\end{array}$ & $396(48 \%)$ & $421(52 \%)$ & $\mathrm{n} / \mathrm{a}$ \\
\hline $\begin{array}{l}\text { Were any of these incidents (teacher, classmate, or relative) reported to } \\
\text { the girls' parents? }(n=393)\end{array}$ & $308(78 \%)$ & $45(11 \%)$ & $40(10 \%)$ \\
\hline $\begin{array}{l}\text { Were any of these incidents (teacher, classmate, or relative) reported to } \\
\text { the police or victim's support unit? }(n=393)\end{array}$ & $232(59 \%)$ & $98(25 \%)$ & $63(16 \%)$ \\
\hline $\begin{array}{l}\text { In any of these incidents (teacher, classmate, or relative), did the girl } \\
\text { seek treatment from the local clinic or hospital? }(n=393)\end{array}$ & $244(62 \%)$ & $69(18 \%)$ & $80(20 \%)$ \\
\hline
\end{tabular}




\section{Personal experience with non-consensual sex}

Twenty-one percent of respondents reported having ever been forced, pressured, coerced, or tricked into having sex. Sixteen percent of girls aged 15-19 who were currently in school reported having had non-consensual sex, compared with 24 percent of out-of school girls reporting so. Eighteen percent of respondents reported having ever been physically or sexually assaulted.

\section{HIV testing knowledge, risk perception, and HIV prevention}

\section{HIV testing}

Seventy-three percent of respondents said they knew a place in their community where one could go to get an HIV test. This proportion was higher in the older age group (84 percent) compared to the younger age group (68 percent) (Figure 7).

Figure 7 Do you know a place where you could go to get an HIVIAIDS test in your community? By age group

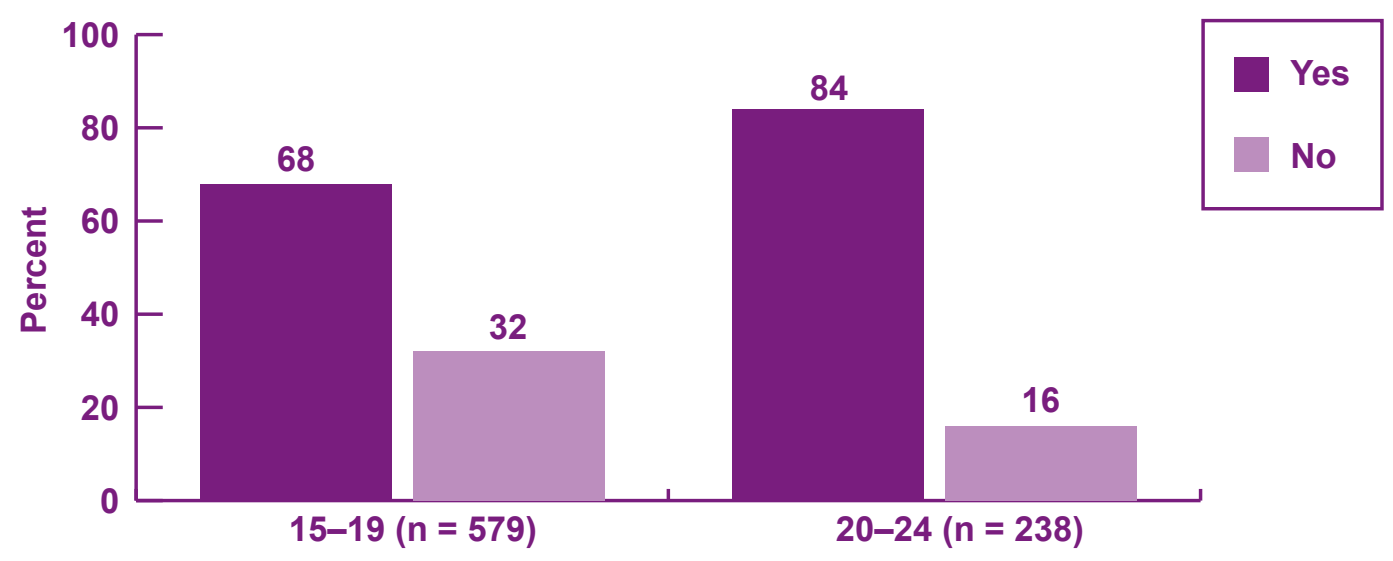

As shown in Figure 8, 33 percent of respondents had ever been tested for HIV. A much greater proportion of the older age group, 60 percent, had ever been tested compared to 22 percent of the younger age group having ever been tested for HIV.

"Some do go for VCT as they have boyfriends and sleep with them, so it's good to know your status you don't know how many sleep with him." 
Figure 8 Have you ever been tested for HIVIAIDS? By age group

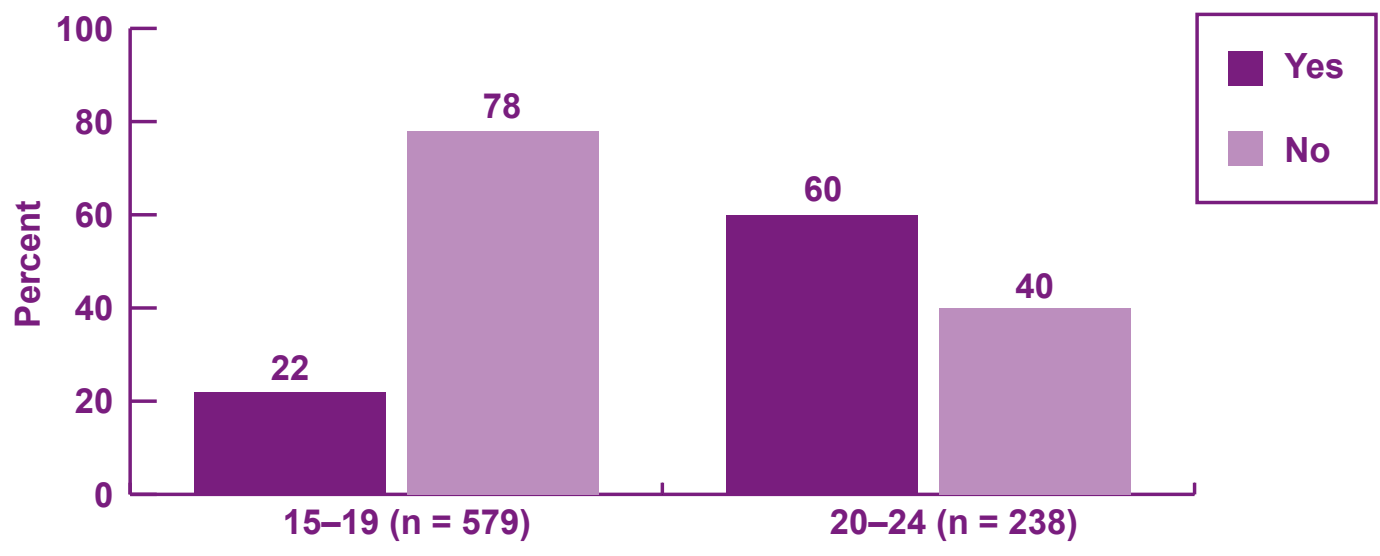

The percentage of in-school girls aged 15-19 who knew a place in their community that provides HIV/AIDS testing was very similar to that of girls not currently in school (68 percent vs. 69 percent, respectively). However, there were significant differences in getting tested: 36 percent of girls not in school had ever been tested for HIV/AIDS, while only 12 percent of girls currently in school had ever been tested.

\section{HIV/AIDS risk perception}

Twenty-six percent of respondents personally knew someone between the ages of 15 and 24 who had HIV/AIDS. Thirty-eight percent of all respondents felt they were at risk for HIV/AIDS. Of those with partners $(n=410), 44$ percent believed they were at risk for HIV/AIDS from their partners. Broken down by partner type, 47 percent of those with steady partners felt at risk from their partner, compared to 39 percent of those with non-steady partners (Figure 9).

Figure 9 Do you believe you are at risk for HIVIAIDS from your partner? By partner type

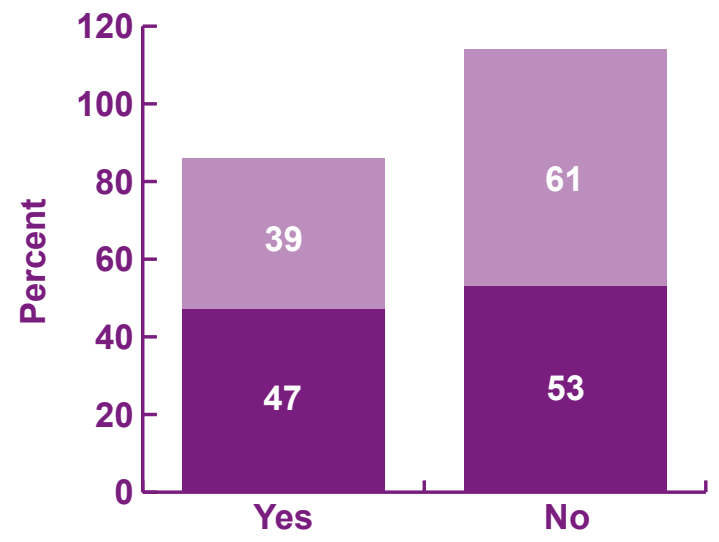

Non-steady partner

Steady partner 
While 33 percent and 35 percent of girls ages 15-19 currently in school and not in school, respectively, said they believed they are personally at risk of HIV (Figure 10), only 27 percent of girls currently in school believed they are at risk specifically from their partners, compared to 44 percent of girls not in school.

"You can know when you are talking to them [girls]... okeay they know the risk and they know how the disease is...so it's like they are scared about it and getting it. Some their reference is good."

-FGD participant

Figure 10 HIVIAIDS risk perception, by in-school status (15-19 year olds)

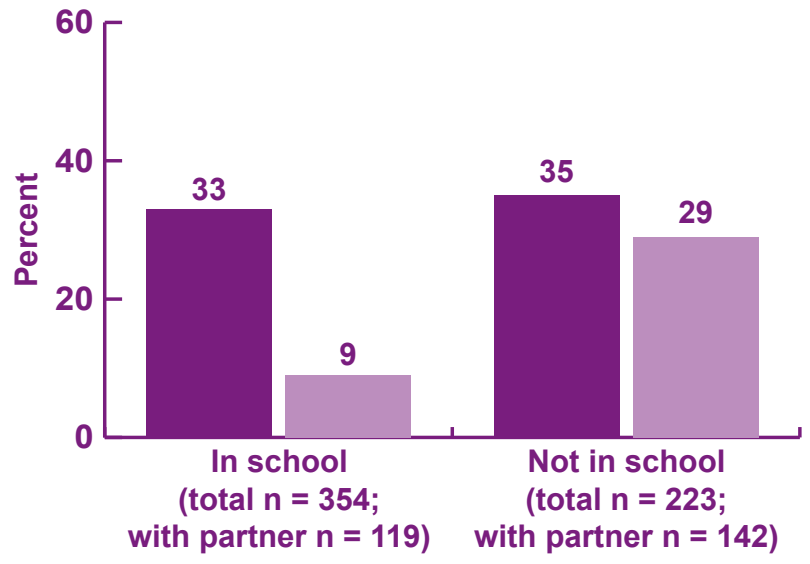

Feel at risk for HIVIAIDS

Feel at risk for HIVIAIDS, specifically from partner (of those with partners)

\section{HIV prevention knowledge}

This study sought to learn about girls' understanding of methods to protect themselves from HIV/AIDS. Using the same battery of questions as the Zambia DHS, we found that 86 percent of respondents correctly knew that there are things a person can do to reduce their chances of getting HIV/AIDS. Of these respondents, 79 percent mentioned abstaining from sex, 67 percent mentioned using condoms, 66 percent mentioned avoiding sharing razors or blades, and 40 percent mentioned limiting sex to one partner or being faithful to one partner (Table 5). 


\begin{tabular}{|c|c|}
\hline & n (\%) \\
\hline Abstinence & $552(79 \%)$ \\
\hline Use condoms & $468(67 \%)$ \\
\hline Avoid sharing razors/blades & $465(66 \%)$ \\
\hline Limit sex to one partner/be faithful to one partner & $281(40 \%)$ \\
\hline Avoid injections & $190(27 \%)$ \\
\hline Avoid blood transfusions & $154(22 \%)$ \\
\hline Avoid kissing & $75(11 \%)$ \\
\hline Avoid sex with prostitutes & $68(10 \%)$ \\
\hline Avoid sex with persons who have many partners & $73(10 \%)$ \\
\hline Avoid sex with persons who inject drugs & $44(6 \%)$ \\
\hline Limit number of sexual partners & $38(5 \%)$ \\
\hline Avoid sex with homosexuals & $27(4 \%)$ \\
\hline Seek protection from a healer & $10(1 \%)$ \\
\hline Avoid mosquito bites & $3(0.4 \%)$ \\
\hline Don't know/none mentioned & $1(0.1 \%)$ \\
\hline
\end{tabular}

\section{HIV prevention approaches}

In addition to navigating their physical and social environments (e.g., not walking alone, staying away from certain places) girls also mentioned specific actions they took to protect themselves. Seventy-nine percent $(n=648)$ of all respondents said they are currently doing something to protect themselves from getting infected with HIV. Of those, 436 (67 percent) said they were abstaining from sex, 155 (24 percent) said they were being faithful to one partner, and 113 (17 percent) said they were using condoms.

\section{Awareness and use of female condom}

Forty-seven percent of respondents believed youth (even adolescents as young as 12) should be taught about the use of condoms to protect against HIV/AIDS. Seventyone percent thought it was acceptable for condoms to be discussed in newspapers, 61 percent believed condoms could be discussed on the radio, and 65 percent believed condoms could be discussed on television. Sixty-six percent of all respondents had ever heard of the female condom, including 83 percent of 20 to 24 year olds and 59 percent of 15 to 19 year olds. (Figure 11). 
Figure 11 Have you ever heard of the female condom? By age group

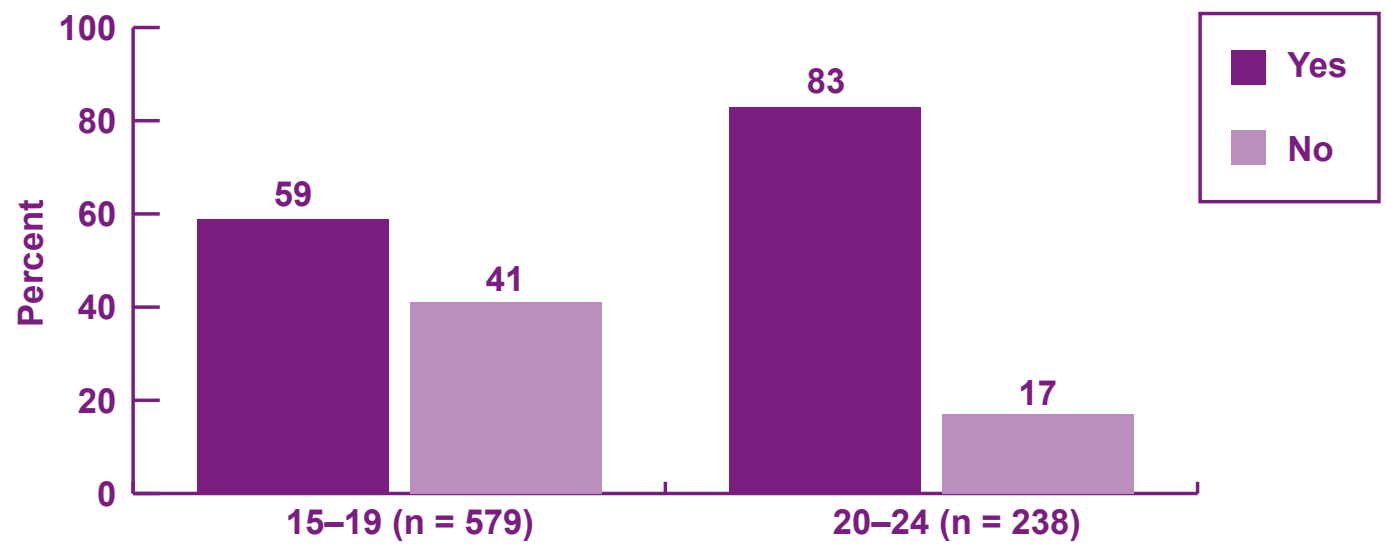

Of those who had heard of the female condom $(n=536), 37$ percent knew where one could get a female condom. Fifty-two percent of those ages 20-24 knew where to get a female condom compared to 29 percent of those ages 15-19. (Figure 12).

Figure 12 Do you know where you can get a female condom? By age group

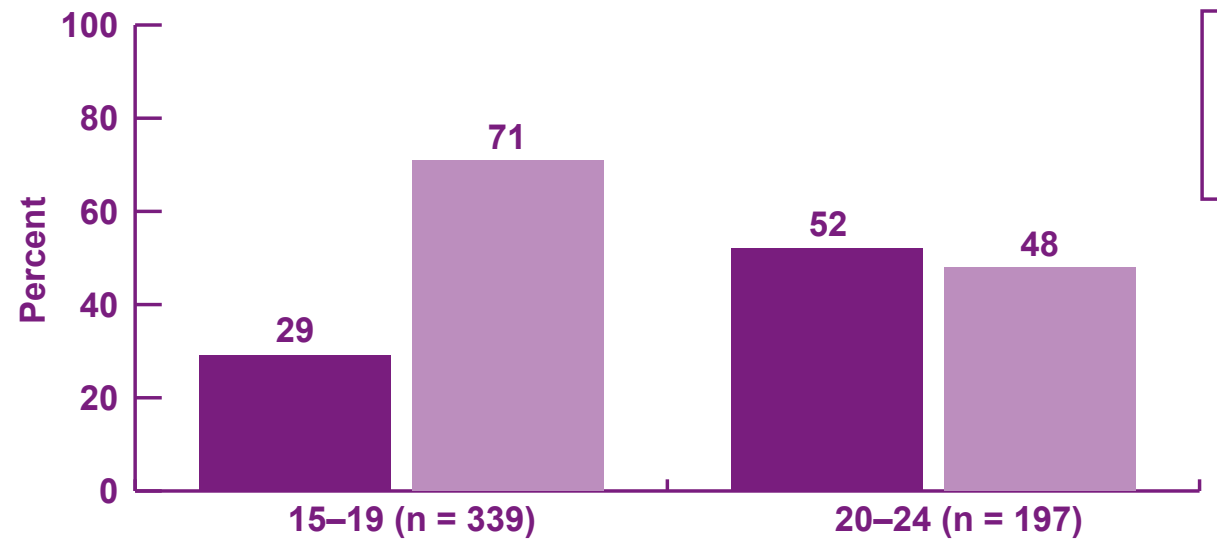

Of those who have ever heard of the female condom ( $n=535), 2$ percent $(10$ respondents) had ever tried to use one. Of these ten respondents, eight were from the older age group. 


\section{Family planning knowledge and use}

Overall, knowledge of family planning was fairly high, with greater awareness among the older cohort. Sixty-one percent of respondents knew of any family planning services in the community. Among 20 to 24 year olds, 85 percent knew of family planning services in their community compared to 51 percent of 15 to 19 year olds (Figure 13).

Figure 13 Do you know of any family planning services in this community? By age group

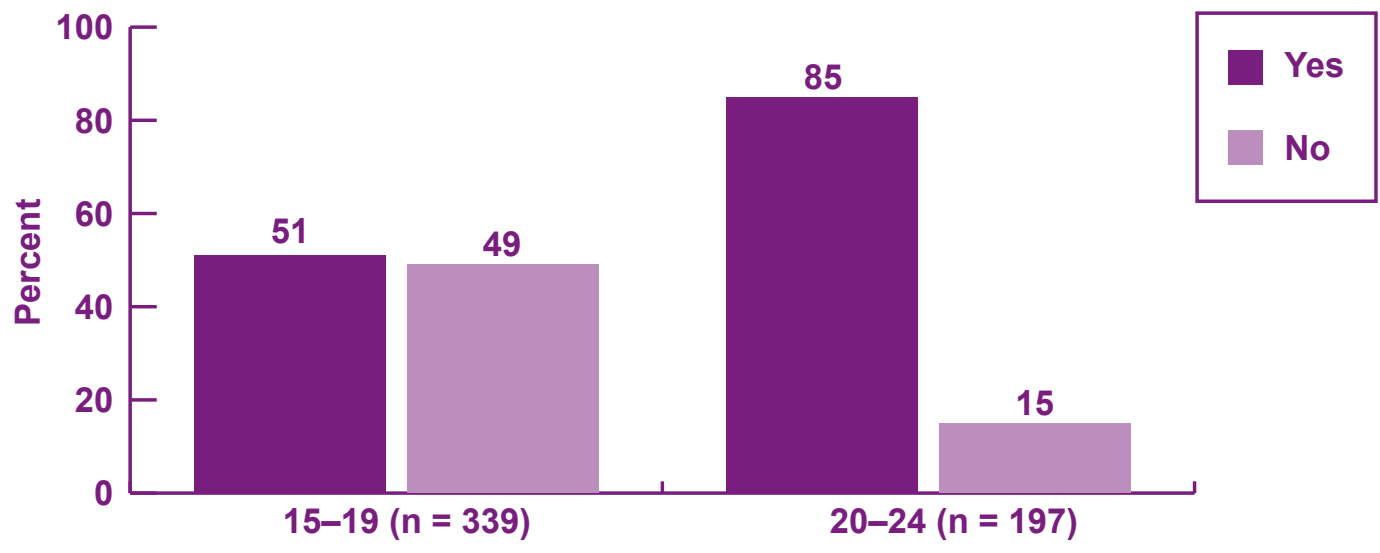

Seventeen percent of respondents reported having ever used the family planning services in their communities. While 44 percent of those between the ages of 20 and 24 had used some family planning, only 5 percent between the ages of 15 and 19 had done so (Figure 14).

Figure 14 Have you ever used the family planning services in this community? By age group

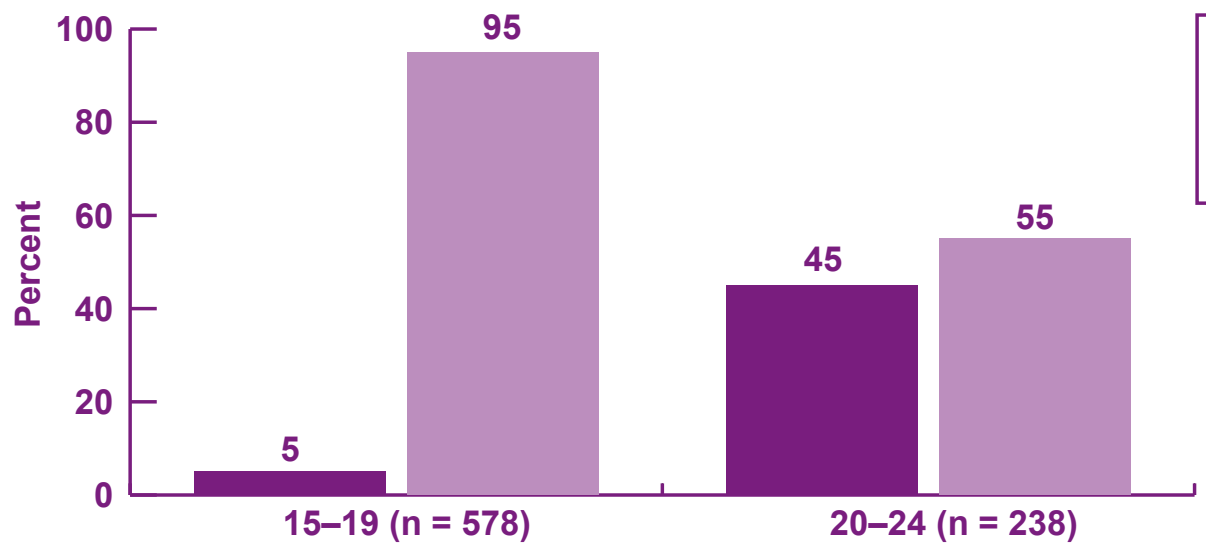


When asked to name all of the modern methods of preventing pregnancy that they had heard of, 95 percent ( $n=226$ ) of all 20 to 24 year olds mentioned oral pills, 75 percent $(\mathrm{n}=178)$ mentioned injections or depo provera, and 55 percent $(n=130)$ mentioned male condoms. Among the younger cohort of 15 to 19 year olds, 74 percent $(\mathrm{n}=$ 426) had heard of oral pills, 44 percent $(n=257)$ had heard of injections, and 42 percent $(n=242)$ had heard of the male condom as ways of preventing pregnancy. Only 12 percent of all respondents had ever heard of emergency contraception, and of those only six respondents had ever used it (Figure 15).
'That's one question which was there when we had a meeting:

'Is it safe for a girl to carry a condom?'

They [the girls] were all like,

No, because if you carry a condom it means you are planning to have sex and you are not supposed to plan.'

I don't think they go to hospitals and clinics for that, they abstain."

—Interview with peer educator

Figure 15 Have you ever heard of emergency contraception? By age group

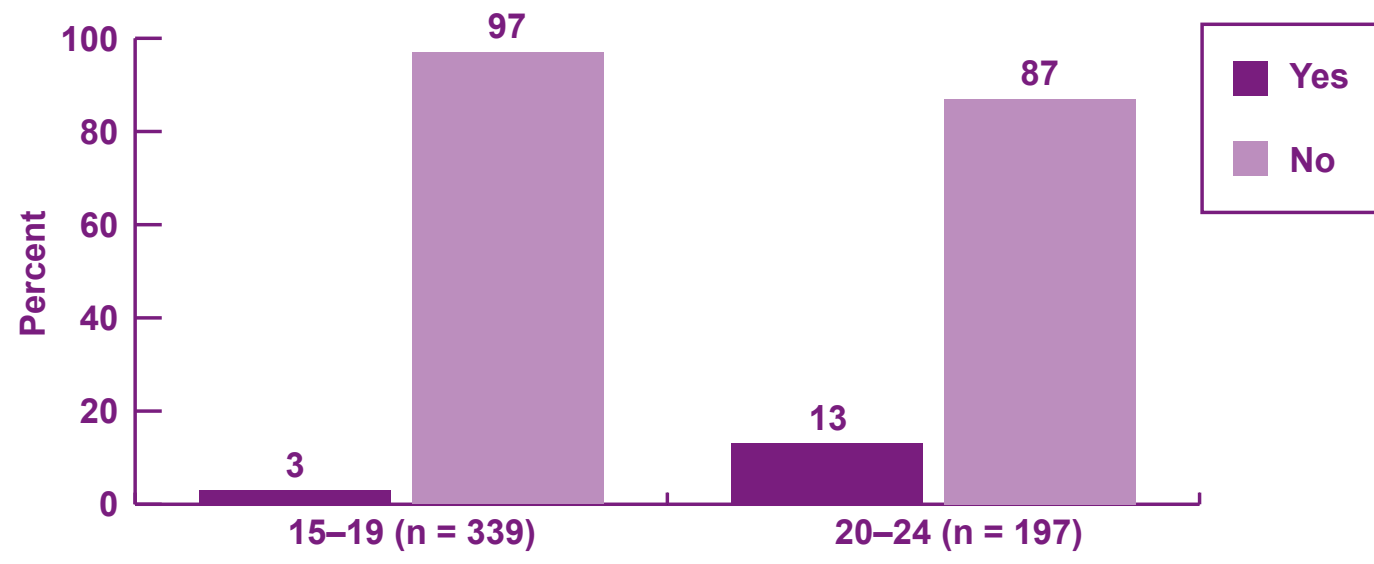

When asked to list all of the methods they had ever used to prevent pregnancy, 30 percent of respondents mentioned abstinence, 13 percent mentioned oral pills, and 11 percent mentioned the male condom. Thirty percent of respondents did not mention any methods.

There were significant differences between the two age groups in their past family planning usage. Among 20 to 24 year olds, 36 percent had tried oral pills, 18 percent had tried the male condom, and 15 percent had tried injectables, compared to only 3 percent, 9 percent, and 1 percent, respectively, of 15 to 19 year olds. Thirty-seven percent of respondents in the 15-19 age group said they had used abstinence to prevent pregnancy, compared to 13 percent of those in the 20-24 age group. Only 18 percent of the older age group said they had not tried any form of modern family planning, compared to 35 percent of the younger age group (Figure 16). 
Figure 16 What methods for preventing pregnancy have you ever tried? By age group

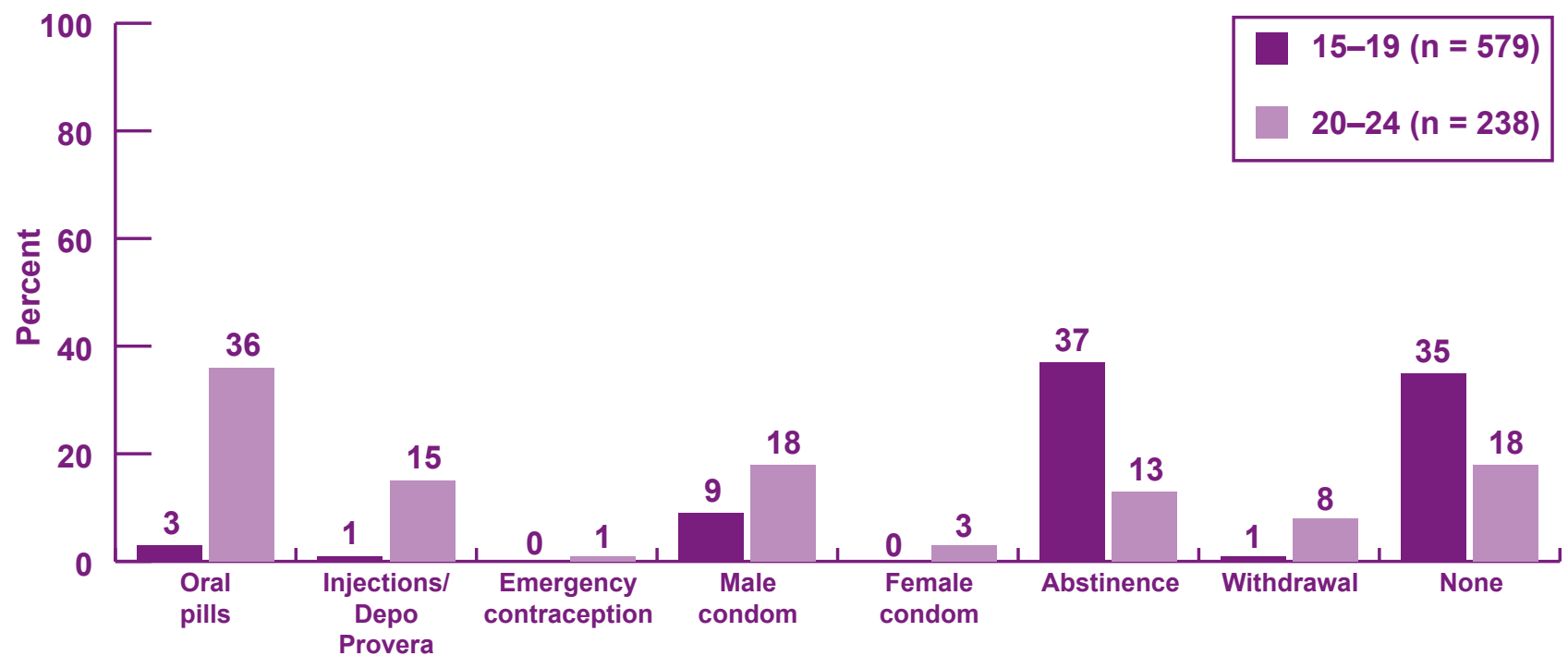

\section{Menstruation and menstrual management}

The onset of menstruation can be a significant social and biological event.

Menstruation carries both a social meaning, as well as practical considerations around hygiene. At the time of the survey, 98 percent of respondents had started menstruation. The majority of respondents ( 69 percent) turned to a female relative such as their mother, grandmother, or aunt for assistance when they first began menstruating. The majority (65 percent) reported using pads or sanitary napkins, a smaller proportion (19 percent) reported using cloth, gauze, or rags, and about 14 percent reported using cotton wool during their menstrual period (Figure 17).

Figure 17 What type of sanitary supplies do you usually use? $(n=799)$

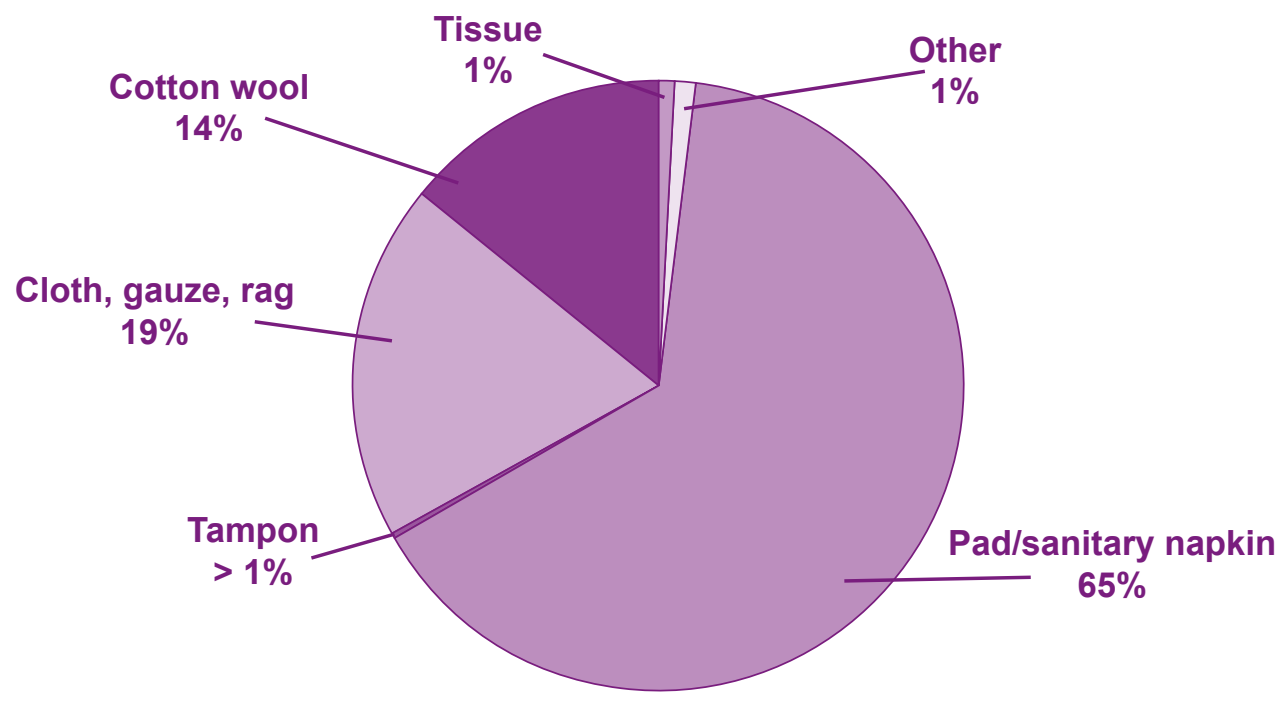


The most common places for procuring sanitary supplies were pharmacies, chemists, or drug stores (36 percent), other shops (29 percent), or a relative or other person (14 percent) (Figure 18). In order to purchase sanitary supplies, 39 percent were given money from their parents, 22 percent used money given to them by their boyfriend or partner, and 18 percent used self-earnings to buy sanitary supplies.

Figure 18 Where do you get sanitary supplies from? $(n=797)$

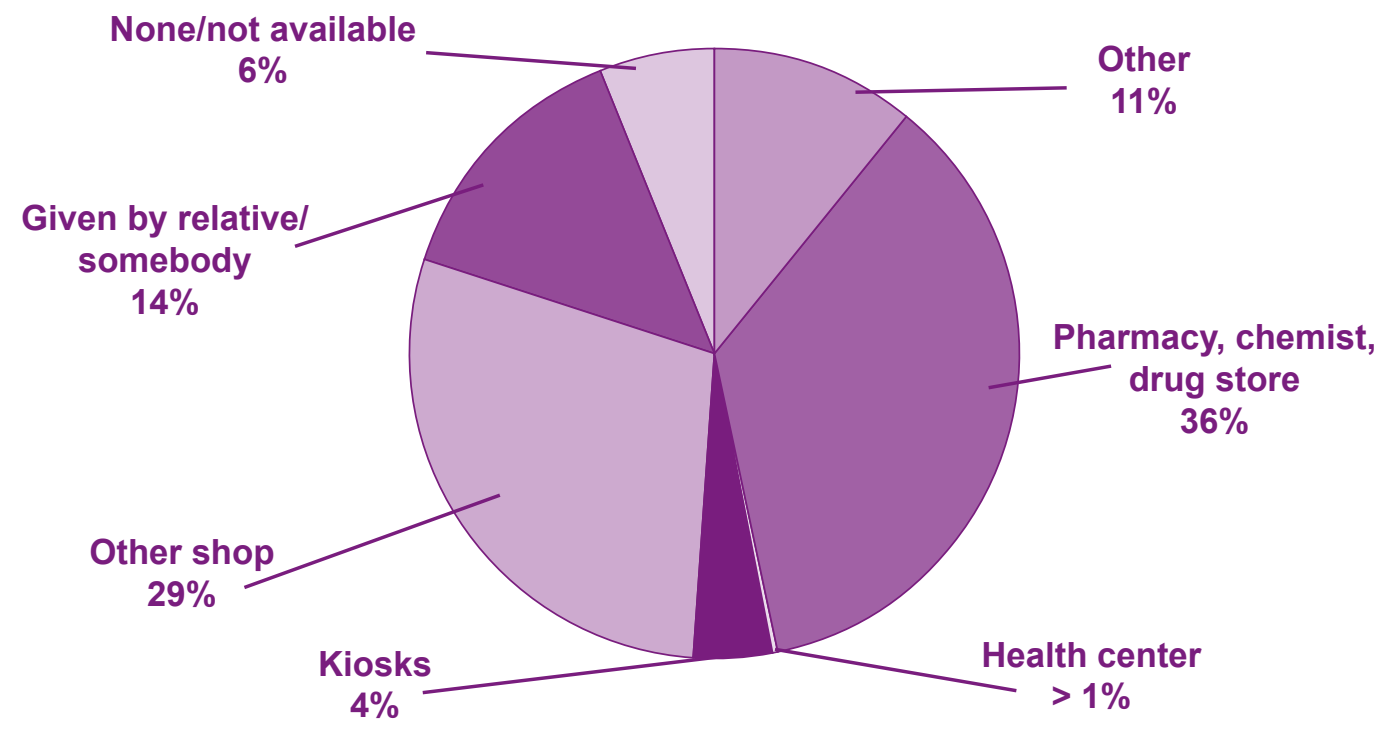

Thirty-six percent of respondents reported that their menstruation had at some point in time caused them to stop participating in daily activities, including sports. Thirtythree percent of those in school said they had at some point had to miss school because of their period.

\section{Sports participation and role models}

Well-designed sports programs have been shown to be empowering for girls, helping to build skills and social assets, and improve girls' sense of agency and competence. Access to sport programs can be limited for girls, as historically this has been viewed as male domain. Increasingly however, girls are participating in sports in many countries. Most school-going girls will have access to some sort of physical education or sport activity in school; those who are not in school have less access, unless specific programs such as Go Sisters, are in place.

Girls reported that the most popular sports that they play were: netball (36 percent), soccer (16 percent), and field athletics (9 percent) (Figure 19). 
Figure 19 Which sports do you play? By age group

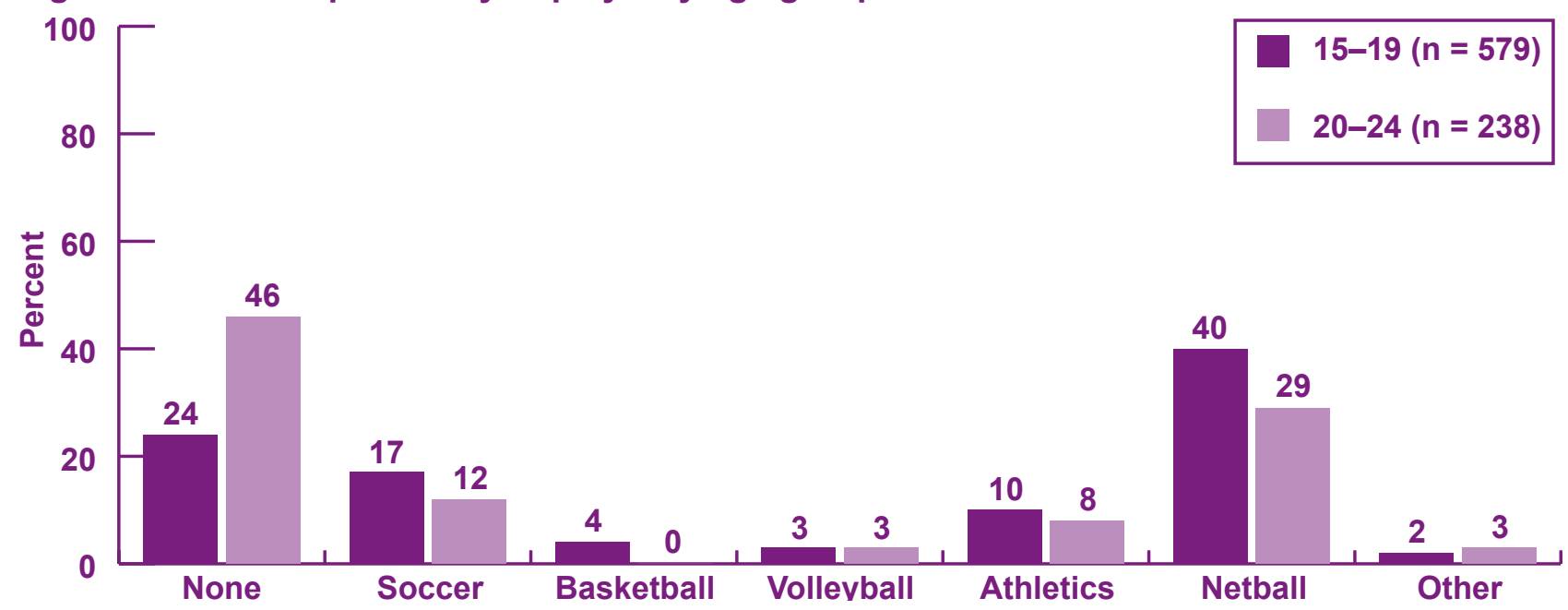

The majority of girls had had some experience playing sports at some time or place, although some did not. Overall 30 percent of respondents said they did not participate in any sports, a greater proportion of the older age group (46 percent) did not play any sports compared to the younger age group, which is consistent with other studies showing that as girls age the likelihood of being engaged in sports decreases. Of those respondents that had ever participated in some sport, almost half had not participated in any sporting activity in the past four months; nearly three quarters of the 20-24 year olds had not done so. And while 41 percent of 15-19 year olds had participated in sports in the last month, only 10 percent of 20-24 year olds had done so (Figure 20).

Figure 20 When did you last participate in any sports activity? By age group

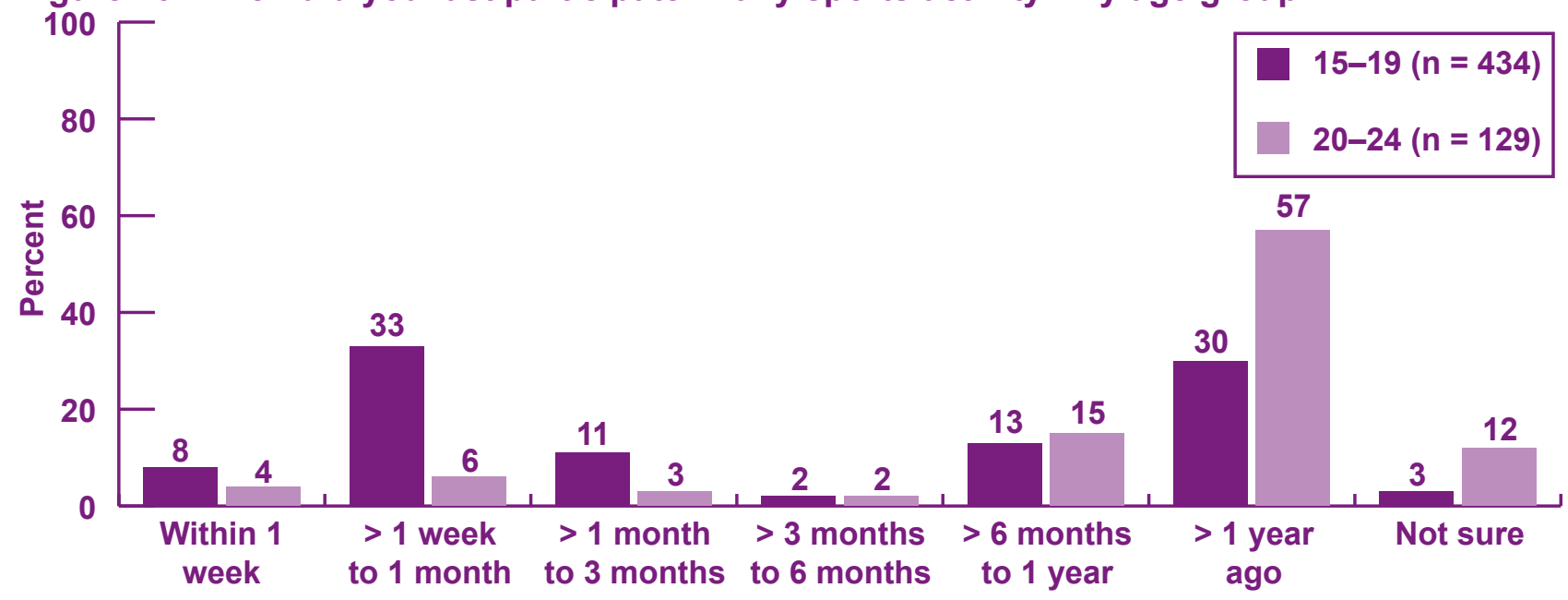


When asked about sports figures they admire, Ester Phiri, the well-known Zambian female boxing champ was most frequently mentioned (Figure 21).

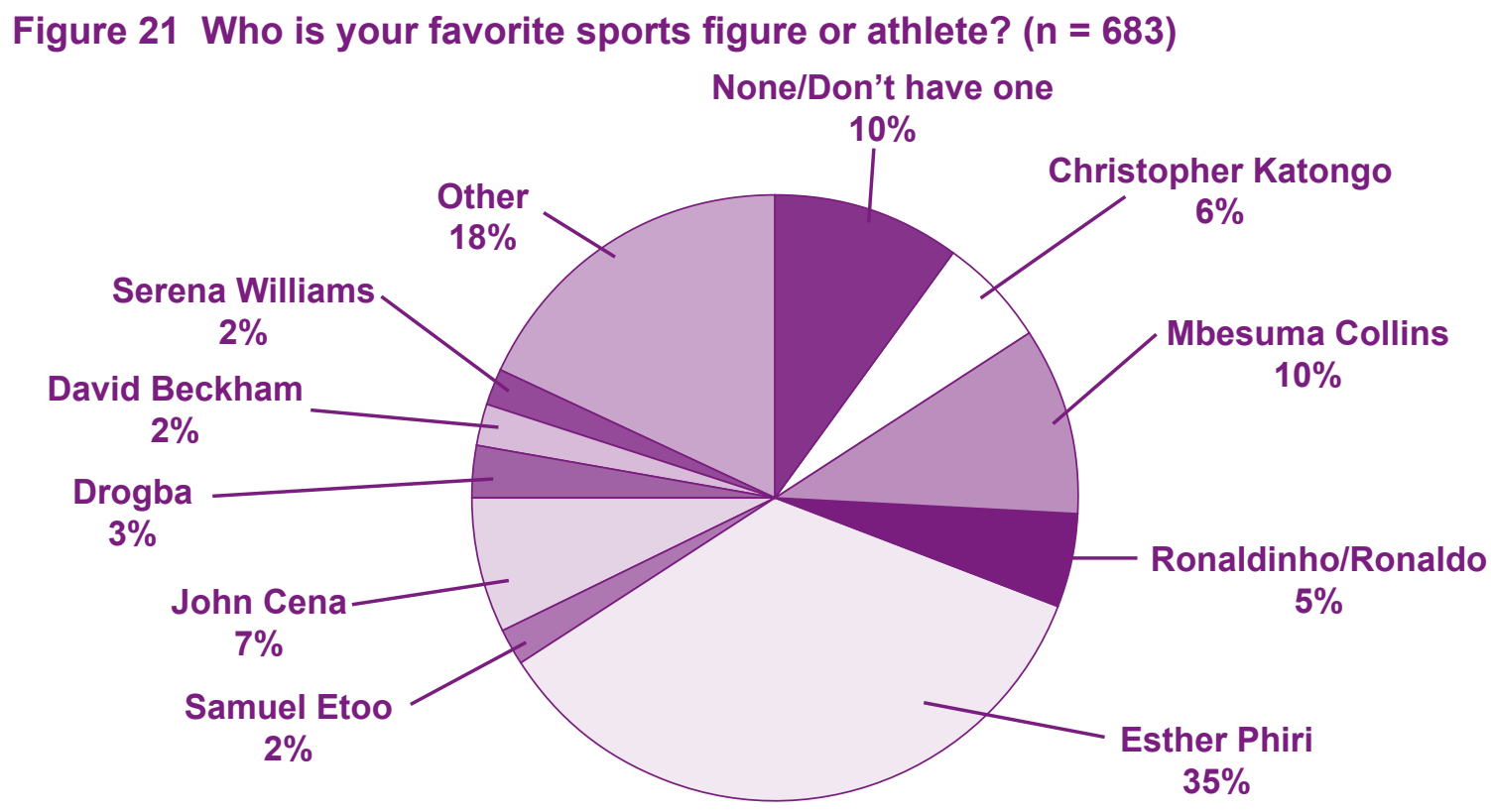

Recruiting and retaining girls in sports programs can be challenging due to the many time pressures and responsibility girls often shoulder. Parental approval of girls' participation must be sought and won. Restrictions on girls' mobility due to safety concerns can be an additional obstacle. However, well-deigned sport programs can provide safe and supportive spaces for girls where they can learn new skills, be part of a team, and have fun.

\section{SUMMARY AND CONCLUSIONS}

The unequal status of girls and women in many societies is central to the development of meaningful HIV protection strategies. This is particularly the case in settings where sexual violence and coercion, high HIV incidence, and women's economic dependence on men leave many young women vulnerable to HIV and AIDS. There is a growing consensus that a focus on broader structural issues, notably gender norms and gender-based violence and inequity, and peer and family support for protective behavior, should be a key focus of future HIV prevention work. The seemingly inescapable perils of being young and female in urban Zambia can be addressed if successful protection strategies are identified and adopted. Girls need strategies that extend beyond information to include new skills and decision making about how to mitigate risk in their social worlds. This research has helped elucidate girls' perspectives 
around key concepts of risk and protection strategies concerning reproductive health, including HIV, as well as physical safety.

This research suggests that girls and young women would benefit from:

- Safe spaces in which to build skills, and develop physical and social assets;

- Broader, deeper, and more robust social support networks;

- Support for education, particularly post-primary education;

- Access to reproductive health information, services and technologies;

- Financial literacy and expanded economic opportunities; and

- Greater protections (legal and social) from gender-based violence. 


\section{REFERENCES}

Aidoo, M. and T. Harpham. 2001. "The explanatory models of mental health amongst low-income women and health care practitioners in Lusaka, Zambia," Health Policy and Planning 16(2): 206-213.

Brady, Martha. 2005. "Creating safe spaces and building social assets for young women in the developing world: A new role for sports," Women's Studies Quarterly 33(1/2): $35-49$.

Central Statistical Office (CSO), Ministry of Health (MOH), Tropical Diseases Research Centre (TDRC), University of Zambia, and Macro International Inc. 2009. Zambia Demographic and Health Survey 2007. Calverton, Maryland, USA: CSO and Macro International Inc.

Central Statistical Office [Zambia], Central Board of Health [Zambia], and ORC Macro. 2003. Zambia Demographic and Health Survey 2001-2002. Calverton, Maryland, USA: Central Statistical Office, Central Board of Health, and ORC Macro.

Denison, J. A. et al. 2006. "Social relationships and adolescents' HV counseling and testing decisions in Zambia," Horizons Research Summary. Washington, DC: Population Council.

Ellen, J. M. et al. 2002. "Adolescent condom use and perceptions of risk for sexually transmitted diseases: a prospective study," Sexually Transmitted Diseases 29(12): 756-62.

Epidemiological Fact Sheet on HIV and AIDS, Zambia 2008 Update, UNAIDS/ WHO/UNICEF.

Gordon, G. and V. Mwale. 2006. "Preventing HIV with young people: a case study from Zambia," Reproductive Health Matters 14(28): 68-79.

Human Rights Watch. 2007. "Violence against schoolgirls." Feb 20, 2007. Accessed at: http://hrw.org/english/docs/2007/02/15/global15342_txt.htm.

Lee, Alison. 2006. "Family matters: Zambia study highlights role of families in youths' testing decisions," Horizons Report, December. Washington, DC: Population Council.

Kalipeni, E., J. Oppong, and A. Zerai. 2007. "HIV/AIDS, gender, agency and empowerment issues in Africa,” Social Science \& Medicine 64(5): 1015-1152.

Magnani, R. J. et al. 2002. "Reproductive health risk and protective factors among youth in Lusaka, Zambia," Journal of Adolescent Medicine 30(1): 76-86. 
Mmari, K. N. and R. J. Magnani. 2003. "Does making clinic-based reproductive health services more youth-friendly increase service use by adolescents? Evidence from Lusaka, Zambia," Journal of Adolescent Health 33(4): 259-270.

Munich, E. and K. M. K. Mayumbelo. 2007. "Methodology to compare costs of sanitation options for low-income peri-urban areas in Lusaka, Zambia," Water $S A$ 33(5): 593-602.

Price, N. and K. Hawkins. 2002. "Researching sexual and reproductive behavior: a peer ethnographic approach,” Social Science \& Medicine 55: 1325-1336.

Project Concern International Zambia and UNICEF Zambia. 2002. "Rapid assessment of street children in Lusaka.” Lusaka: Project Concern International and UNICEF.

Slonim-Nevo, V. and L. Mukuka. 2005. "AIDS-related knowledge and behavior among adolescents in Zambia," AIDS and Behavior 9(2): 223-231.

Stringer, E. M. et al. 2004. "Personal risk perception, HIV knowledge and risk avoidance behavior, and their relationships to actual HIV sero-status in an urban African obstetric population," Journal of Acquired Immune Deficiency Syndrome 35(1): 60-66.

UNAIDS. 2008. “2008 Report on the Global AIDs Epidemic, Annex 1.” Geneva: UNAIDS.

Underwood, C. et al. 2006. "Reducing the risk of HIV transmission among adolescents in Zambia: psychosocial and behavioral correlates of viewing a risk-reduction media campaign," Journal of Adolescent Health 38: 55 e1-e13.

The World Bank. 2002. "Upgrading of low income settlements: Zambia country assessment report.” Geneva: The World Bank. 




\section{(2) Population Council}

www.popcouncil.org

Population Council

One Dag Hammarskjold Plaza

New York, New York 10017

USA

Telephone: +1 2123390500

Facsimile: +1 2127556052 